\title{
Effects of Dietary Supplementation of Spirulina platensis and Garlic on the Growth Performance and Expression Levels of Immune-related Genes in Nile tilapia (Oreochromis niloticus)
}

\author{
Nermeen M Abu-Elala ${ }^{1 *}$, Mona K Galal ${ }^{2}$, Reham M Abd-Elsalam ${ }^{3}$, Omnia Mohey-Elsaeed ${ }^{4}$ and Naela M Ragaa ${ }^{5}$
}

${ }^{1}$ Department of Fish Diseases and Management, Faculty of Veterinary Medicine, Cairo University, Giza, Egypt

${ }^{2}$ Department of Biochemistry and Chemistry of Nutrition, Faculty of Veterinary Medicine, Cairo University, Giza, Egypt

${ }^{3}$ Department of Pathology, Faculty of Veterinary Medicine, Cairo University, Giza, Egypt

${ }^{4}$ Department of Cytology and Histology, Faculty of Veterinary Medicine, Cairo University, Giza, Egypt

${ }^{5}$ Department of Nutrition and Clinical Nutrition, Faculty of Veterinary Medicine, Cairo University, Giza, Egypt

\begin{abstract}
Sixty days feeding trial was carried out to investigate the supplemental effects of dietary phytobiotic mixture composed of Spirulina platensis powder (SP) and Garlic powder (GP) on the growth performance, intestinal morphometry, and immune responses of Nile tilapia Oreochromis niloticus. A total of 240 cultured $O$. niloticus $(41.4 \pm 0.09 \mathrm{~g})$ were randomly divided into four experimental groups (three replicate/group), fed on basal diets contain $0 \%$ (control), $1 \%(\mathrm{SP}), 0.5 \%$ (GP), or a combination of both (SP + GP). Fish group fed on phytobiotic mixture showed significant improvements in its feed intake, live weight gain, specific growth rate, feed conversion ratio and protein efficiency ratio $(p<0.05)$, associated with a healthy gut, compared to non-supplemented control. Dietary supplementation of phytobiotics appeared to stimulate the humoral and cellular innate immunity. Fish group that were fed on phytobiotic mixture revealed up-regulation in some immune related genes; TNF- $\alpha$ and liver hepcidin as well as it exhibited the least cumulative mortality \% upon $A$. hydrophila infection. So we can conclude that dietary supplementation of garlic and Spirulina have been improved the growth performance, gut health, immune status and disease resistance in Nile tilapia.
\end{abstract}

Keywords: Phytobiotic; Growth; Immunity; Cytokines; Antimicrobial peptide; Gut health

\section{Introduction}

Aquaculture production of Nile tilapia, O. niloticus has been increased significantly in Egypt and most tropical countries [1]. However, the wide expansion of this blue revolution faces several infectious diseases and certain management practices that potentially damage human and animal health [2]. Hence, there is an augmenting curiosity for application of innovative management strategies to improve the aquatic welfare and production of safe food [3]. In this context, phytobiotics have recently attracted significant attention in aquaculture as they have various repertoire of active principles with very potent immunostimulant, antioxidant and antimicrobial properties $[4,5]$.

Spirulina alga (Arthrospira platensis) (SP) is a primitive planktonic photosynthetic filamentous cyanobacterium that has a simple structure but a complex composition [6]. Based on the nutraceutical properties of Spirulina urge, it was considered by the United Nations as the possible "best food for the future" or "Super food" [6]. It contains highly digestible protein $(60-70 \%)$ with all essential amino acids, polyunsaturated fatty acids such as $\gamma$-linolenic acid, vitamins, minerals and various photosynthetic pigments $[7,8]$. The therapeutic uses of Spirulina and its biological derivatives in human medicine are promoting their applications in aquaculture especially in tropical and sub-tropical countries where it has been cultivated [9]. Inclusion of $S$. platensis in fish diet as a feed additive or as a partial replacer of the expensive fishmeal imposes significant promotions in fish growth, coloration, reproduction and flesh quality [10-13]. Previous studies suggested that bioactive constituents of $S$. platensis like phycocyanin, $\beta$-carotene, $\gamma$-linolenic acid and phenolic compounds give this type of macrophytes its powerful antioxidant, antimicrobial, immunostimulant, and resistance against diseases [14-20].

Garlic, Allium sativum, (GP) is another phytobiotic of interest. It is one of the most effective natural immunostimulants with a reputation as an "all-healing" herb [21]. Garlic and its biological derivatives are known to have many attributes in human and animal medicine such as hypolipidemic, antiatherosclerotic, antitumorigentic, antimicrobial, antihypertensive, hepatoprotective, insecticidal, and immunostimulant [21]. These beneficial effects of garlic are due to presence of various biological organo-sulphur compounds particularly, allicin which is responsible for the pungent garlic flavor, strong food calling effect, antimicrobial and immunostimulant properties [22]. Dietary inclusion of garlic in finfish and shrimp food formulas significantly improved growth performance, immunity and resistance against diseases [2327]. Most of the aquatic garlic studies were performed to estimate the optimal beneficial dietary inclusion levels. The overall findings suggested that high concentrations of this additive may result in negative impact on fish health [28] especially in fries and fingerlings $[29,30]$. Therefore optimization of affordable formulation and alleviated toxicity is needed. Few studies suggested a potential synergistic effect of garlic with other phyto-additives [31-33] and this suggestion needs further investigation before such treatment can be used in practice. So the aim of the present study is to determine the synergistic effect of Garlic and Spirulina on the growth performance, gut health, immunity, and disease resistance of cultured tilapia with special emphasis to the modulation of these phytobiotics on immune related genes such as tumer necrosis factor- $\alpha$ (TNF- $\alpha$ ) and antimicrobial peptid (hepcidin) as important immune system mediators.

${ }^{*}$ Corresponding author: Dr. Nermeen M Abu-Elala, Department of Fish Diseases and Management, Faculty of Veterinary Medicine, Cairo University Giza, 11221, Egypt, Tel: 01067114455; Fax: +202-35725240, +202-35710305 E-mail: Nermeen_abuelala@cu.edu.eg

Received July 05, 2016; Accepted July 21, 2016; Published July 23, 2016

Citation: Abu-Elala NM, Galal MK, Abd-Elsalam RM, Mohey-Elsaeed O, Ragaa NM (2016) Effects of Dietary Supplementation of Spirulina platensis and Garlic on the Growth Performance and Expression Levels of Immune-related Genes in Nile tilapia (Oreochromis niloticus). J Aquac Res Development 7: 433. doi:10.4172/2155-9546.1000433

Copyright: (C) 2016 Abu-Elala NM, et al. This is an open-access article distributed under the terms of the Creative Commons Attribution License, which permits unrestricted use, distribution, and reproduction in any medium, provided the original author and source are credited. 
Citation: Abu-Elala NM, Galal MK, Abd-Elsalam RM, Mohey-Elsaeed O, Ragaa NM (2016) Effects of Dietary Supplementation of Spirulina platensis and Garlic on the Growth Performance and Expression Levels of Immune-related Genes in Nile tilapia (Oreochromis niloticus). J Aquac Res Development 7: 433. doi:10.4172/2155-9546.1000433

Page 2 of 10

\section{Materials and Methods}

\section{Experimental fish}

A total of 240 apparently healthy O. niloticus weighing $41.4 \pm$ $0.09 \mathrm{~g}$ were obtained from commercial fish farm. Fish acclimated to laboratory conditions for two weeks before being randomly divided into four dietary groups. A total of 60 fish was allocated to each dietary group in three independent replicates. The experimental fish were weighed every 15 days in order to adjust the daily feed rate which was $2 \%$ of the total biomass (NRC, 1993) at two times/ day (8.00 am, and $4.00 \mathrm{pm}$ ) for two months. All experiments were approved by the ethical committee of Cairo University.

\section{Experimental unit}

The experimental fish were stocked in 12 glass aquaria ( $100 \times 30$ $\mathrm{x} 40 \mathrm{~cm}$ ) supplied with de-chlorinated tap water. Water was aerated continuously using an air compressor. Photoperiod was $12 \mathrm{~h}$ light and $12 \mathrm{~h}$ dark. Water temperature was maintained at $24 \pm 1^{\circ} \mathrm{C}$ using a 250 watt immersion heater with thermostat. Water temperature and dissolved oxygen were recorded daily (by metteler Toledo, model 128.s/No1242) where the average range of dissolved oxygen was above $5.8 \mathrm{mg} / \mathrm{l}$. Other water quality parameters including $\mathrm{pH}$ and ammonia were measured every two days by a $\mathrm{pH}$ meter (HI 98127 - Hanna instruments Inc., RI, USA) and ammonia meter (Hanna ammonia meter, Hanna instruments Inc., RI, USA) respectively, where the average range of total ammonia was $0.12-0.23 \mathrm{mg} / \mathrm{l}$ and $\mathrm{pH}$ was in the range of $7.2 \pm 0.5$ during the experiment.

\begin{tabular}{|c|c|}
\hline Ingredient & $\%$ \\
\hline Fish meal $(67 \%)$ & 8.4 \\
\hline Soy bean meal $(48 \%)$ & 36 \\
\hline Yellow Corn & 39.34 \\
\hline Corn gluten $(60 \%)$ & 3 \\
\hline $\begin{array}{l}\text { Corn starch } \\
\text { Soy and fish oil }\end{array}$ & $\begin{array}{c}6.55 \\
4\end{array}$ \\
\hline Vitamin C & 0.01 \\
\hline $\begin{array}{c}\text { Mono calcium phosphate } \\
(23.7)\end{array}$ & 0.2 \\
\hline Calcium carbonate & 1.5 \\
\hline Sodium chloride & 0.7 \\
\hline${ }^{1}$ Premix & 0.3 \\
\hline $\begin{array}{c}\text { Chemical analysis of the } \\
\text { diet }\end{array}$ & (\%) \\
\hline Moisture & 10 \\
\hline Dry matter & 90 \\
\hline Ash & 4.44 \\
\hline Ether extract & 6.67 \\
\hline Crude fiber & 3.6 \\
\hline Crude protein & 28 \\
\hline${ }^{3} \mathrm{NFE}$ & 45.98 \\
\hline${ }^{4}$ Gross energy kcal/100g & 415.12 \\
\hline
\end{tabular}

${ }^{1}$ Each $\mathrm{Kg}$ vitamin and mineral mixture premix contained Vitamin $\mathrm{A}: 4.8$ million IU, D3: 0.8 million IU; Vitamin E: $4 \mathrm{~g}$; Vitamin K: $0.8 \mathrm{~g}$; Vitamin B1: $0.4 \mathrm{~g}$; Riboflavin: $1.6 \mathrm{~g}$; Vitamin B6: $0.6 \mathrm{~g}$; Vitamin B12: $4 \mathrm{mg}$; Pantothenic acid: $4 \mathrm{~g}$; Nicotinic acid: 8 g; Folic acid: 0.4 g; Biotin: 20 mg; Mn: 22 g; Zn: 22 g; Fe: 12 g; Cu: 4 g; I: 0.4 g; Selenium: $0.4 \mathrm{~g}$ and Co: $4.8 \mathrm{mg}$

${ }^{3}$ Nitrogen free extract.

${ }^{4} \mathrm{Gross}$ energy. Based on $5.65 \mathrm{Kcal} / \mathrm{g}$ protein, $9.45 \mathrm{Kcal} / \mathrm{g}$ fat and 4.1 carbohydrate $\mathrm{Kcal} / \mathrm{g}$ (NRC, 1993).

Table 1: Ingredients and composition of experimental diet.

\section{Experimental diets}

Four iso-nitrogenous diets were formulated to satisfy the nutrient requirements of O. niloticus according to NRC 1993 [34] (Table 1), basic diet was supplemented with either $10 \mathrm{~g} / \mathrm{kg}$ Spirulina platensis (SP; Organic Spirulina powder cultivated in China, Nukraft company, London, UK), 5 g/kg Garlic (GP; Garlic powder, Natural mountain life company, Aswan, Egypt), or a mixture of $10 \mathrm{~g}$ S. platensis and $5 \mathrm{~g}$ Garlic/ kg feed (SP + GP). Control diet received no supplementation. The experimental diets were formulated to contain $28 \%$ crude protein. The diets were prepared by weighing each components and mixing them vitamins, minerals and the examined feed additives. Water was added until the mixture became suitable for making pellets using a pellet machine with $2 \mathrm{~mm}$ in diameter. The produced pellets were dried at room temperature and kept frozen until experiment start. The tested diets were analyzed using the procedures described by standard A.O.A.C. methods [35] (Table 1). The nitrogen free-extract (NFE\%) was calculated by differences.

\section{Growth performance and feed utilization}

The body weight of fish per group was recorded on the individual basis biweekly intervals for two months. The growth parameters were measured at the end of feeding trial as follow:

- Weight gain $(\mathrm{WG})$ = average final weight $(\mathrm{g})$ - average initial weight $(\mathrm{g})$.

- Specific growth rate (SGR) $=($ Ln. Final body weight- Ln. Initial body weight) x 100/experimental period (days).

- Protein efficiency ratio $(\mathrm{PER})=$ weight gain $(\mathrm{g}) /$ protein intake $(\mathrm{g})$.

- Feed conversion ratio (FCR) = feed intake (g)/body weight gain ( $\mathrm{g}$ ).

\section{Histological examination}

At the end of the feeding period, samples from Kidney, Liver and anterior intestine were collected from (five fish/group/replicate). The intestinal samples were gently flushed with Phosphate Buffered Saline to remove the intestinal contents and all tissues were preserved in $10 \%$ neutral buffered formalin for $48 \mathrm{~h}$. They were then processed by routine paraffin embedding technique, sectioned at $5 \mu \mathrm{m}$ thickness and stained with Hematoxylin and Eosin (H\&E) [36].

In the morphometric study, the height of 5 villi and depth of 5 crypts were measured per section and in 3 sections per fish. The villi length was measured from tip to base, and then the crypt depth was measured from the base of the villi to the base of the crypt. Villus heights and crypt depths were measured in Lieca Qwin 500 Image Analyzer (Leica, Cambridge, England). The mean value of each fish was obtained and used for statistical analysis.

\section{Sampling}

Blood and tissue samples were collected ( $n=5 /$ group/replicate) at the end of experimental period to evaluate the innate immunity of fish groups; Oxidative burst and lysozyme activities as well as some immune genes expression such as TNF- $\alpha$ and liver hepcidin. The whole blood samples were drawn from the caudal vessels onto 100 $\mathrm{IU} / \mathrm{ml}$ sodium heparin to estimate the respiratory burst activity and without anticoagulant to determine the serum lysozyme activity as detailed below. Tissue samples from liver, spleen and anterior kidney were collected to perform the total RNA extraction.

\section{Immunological assays}

Reactive oxygen species (ROS) production of the intracellular 
Citation: Abu-Elala NM, Galal MK, Abd-Elsalam RM, Mohey-Elsaeed O, Ragaa NM (2016) Effects of Dietary Supplementation of Spirulina platensis and Garlic on the Growth Performance and Expression Levels of Immune-related Genes in Nile tilapia (Oreochromis niloticus). J Aquac Res Development 7: 433. doi:10.4172/2155-9546.1000433

Page 3 of 10

\begin{tabular}{|l|l|l|c|}
\hline $\begin{array}{l}\text { Gene } \\
\text { name }\end{array}$ & Accession number & primers & Product size \\
\hline TNF-a & LOC100534578 & $\begin{array}{l}\text { GTCGTCGTGGCTCTTTGTTT } \\
\text { TGCTGATCCGTTTTAGCGTG }\end{array}$ & 157 \\
\hline $\begin{array}{l}\text { Liver } \\
\text { hepcidin }\end{array}$ & AYC25227.2 & $\begin{array}{c}\text { CTGGAGAGCATTGTGGAAGC } \\
\text { GCACTATGCGGTCTTCACTG }\end{array}$ & 219 \\
\hline GAPDH & NM_001279552.1 & $\begin{array}{l}\text { GCTGTACATGCACTCCAAGG } \\
\text { ACTCAAACACACTGCTGCTG }\end{array}$ & 182 \\
\hline
\end{tabular}

Table 2: Gene accession number and primers used in this study.

\begin{tabular}{|l|c|c|c|c|}
\hline Items & Control & S. platensis & Garlic & $\begin{array}{c}\text { S. platensis } \\
+ \\
\text { Garlic }\end{array}$ \\
\hline Initial weight & $41.5 \pm 5.42^{\mathrm{a}}$ & $41.6 \pm 4.42^{\mathrm{a}}$ & $41.4 \pm 6.32^{\mathrm{a}}$ & $41.2 \pm 6.22^{\mathrm{a}}$ \\
\hline Final weight & $97.2 \pm 10.56^{\mathrm{a}}$ & $108.75 \pm 11.74^{\mathrm{b}}$ & $115.75 \pm 11.84^{\mathrm{c}}$ & $\begin{array}{c}120.1 \pm \\
12.53^{\mathrm{d}}\end{array}$ \\
\hline $\begin{array}{l}\text { Total feed } \\
\text { intake /fish/2M }\end{array}$ & $149.36^{\mathrm{a}}$ & $164.91^{\mathrm{b}}$ & $175.8^{\mathrm{c}}$ & $182.53^{\mathrm{d}}$ \\
\hline Weight gain & $55.7 \pm 6.12^{\mathrm{a}}$ & $67.15 \pm 7.95^{\mathrm{b}}$ & $74.35 \pm 7.88^{\mathrm{c}}$ & $78.9 \pm 7.92^{\mathrm{d}}$ \\
\hline${ }^{1}$ SGR & $1.13 \pm .0107^{\mathrm{a}}$ & $1.28 \pm 0.127^{\mathrm{b}}$ & $1.37 \pm 0.139^{\mathrm{c}}$ & $1.42 \pm 0.129^{\mathrm{d}}$ \\
\hline${ }^{2} \mathrm{PER}$ & $1.33 \pm 0.41^{\mathrm{a}}$ & $1.45 \pm 0.138^{\mathrm{b}}$ & $1.51 \pm 0.163^{\mathrm{c}}$ & $1.54 \pm 0.161^{\mathrm{c}}$ \\
\hline${ }^{3} \mathrm{FCR}$ & $2.68 \pm 0.30^{\mathrm{a}}$ & $2.46 \pm 0.33^{\mathrm{b}}$ & $2.36 \pm 0.25^{\mathrm{c}}$ & $2.31 \pm 0.31^{\mathrm{d}}$ \\
\hline
\end{tabular}

Data represented as means $\pm S E$ ( $n=15 /$ group/replicate). Within rows, values with different superscripts $a, b, c$ and $d$ are significantly different at $(p<0.05)$ according to one way ANOVA followed by Duncan test. Specific growth rate, 2- Protein efficiency ratio, 3-Feed conversion ratio.

Table 3: Growth performance of $O$. niloticus at the end of feeding trial.

respiratory burst activity of activated macrophages was measured by NBT method [37] Lysozyme activity of serum samples was determined using a turbidimetric assay [38].

\section{Tissue RNA Extraction and Quantitative Real-time PCR}

Total RNA was extracted from $50 \mathrm{mg}$ of tilapia tissues using Qiagen RNeasy Mini Kit following the manufacturer's protocol. The homogenization of the samples was performed with a pestle microhomogenizer in $1.5 \mathrm{ml}$ Eppendorf tube. Total RNA yields and purity were determined by measuring the absorbance at 260 and $280 \mathrm{~nm}$ using Spectrophotometer (Thermo Scientific, USA). cDNA synthesis was carried out using reverse transcriptase kit (Thermo Scientific, USA) and oligo-dT following the manufacturer protocol. After initial heat denaturation of $1 \mu \mathrm{g}$ of total RNA $\left(65^{\circ} \mathrm{C}\right.$ for $\left.5 \mathrm{~min}\right)$, the reactions $(20 \mu \mathrm{l})$ were incubated for one hour at $42^{\circ} \mathrm{C}$ and then for $15 \mathrm{~min}$ at $85^{\circ} \mathrm{C}$. cDNA was added to a SYBR Green qPCR Master Mix (Qiagen) containing $30 \mathrm{pg} / \mathrm{ml}$ of primer pairs specific for target genes (Table 2) designed using the Primer 3 program. After initial denaturation at $95^{\circ} \mathrm{C}$ step for $1 \mathrm{~min}, 40$ cycles were used: denaturation at $95^{\circ} \mathrm{C}$ for 15 $\mathrm{s}$, annealing at $57^{\circ} \mathrm{C}$ for $20 \mathrm{~s}$ and extension at $72^{\circ} \mathrm{C}$ for $45 \mathrm{~s}$. The size of all amplicons was confirmed on $2 \%$ agarose gel electrophoresis stained with SYBR Safe DNA gel stain (Invitrogen). GAPDH mRNA [39] was amplified in the same reaction to serve as a reference gene. Gene expression levels were calculated and determined following the method described by Schmittgen and Livak [40].

\section{Bacterial infection}

An experimental infection was induced in the remaining fish ( $\mathrm{n}=10 /$ group/replicate) with pathogenic bacteria Aeromonas hydrophila LC012347 [41]. The bacteria were grown overnight in trypticase soya broth (TSB, Difco, USA) and the concentration was adjusted to $1.0 \times 10^{6}$ $\mathrm{CFU} / \mathrm{ml}$ in PBS. Fish groups were injected with $0.2 \mathrm{ml}$ of the bacterial suspension intra-peritoneally (I.P.). Two days post infection; five fish/ group/replicate were sampled to collect blood and tissue samples for immunological and histopathological evaluations post infection.

\section{Histopathological examination}

The tissues specimens were collected from liver, kidneys, gills and spleen of the different fish groups after experimental infection. They were fixed in $10 \%$ neutral buffered formalin and routinely processed to get 3-4 $\mu \mathrm{m}$ sections. The tissue sections were stained with hematoxylin and eosin [36].

\section{Immuno-histochemistry for evaluation of TNFa protein ex- pression}

The immune-histochemical staining procedures were performed following the method described by Ronza et al. [42]. For antigenic retrieval, tissue sections were pretreated with $10 \mathrm{mM}$ citrate buffer, pH 6.0 in microwave oven for 10 minutes at $500 \mathrm{~W}$. Sections were incubated overnight with rabbit polyclonal anti-human TNF alpha (ab6671; Abcam, Cambridge, UK) at 1: 100 dilutions. The sections were incubated with a goat anti-rabbit immunoglobulin antibody (Thermo scientific, USA) for $10 \mathrm{~min}$. PBS was used instead of primary antibodies for negative controls.

The protein expressions of TNFa immunostaining were examined in the cells of Liver, kidney and spleen. The immune-stained sections of different experimental groups were randomly counted in ten microscopic fields under power field (X1000) microscope. In each field, positive cells and total cell number were counted. Percentage of positive stained cells (\%) was calculated. The image analysis was done by Lieca Qwin 500 Image Analyzer (Leica, Cambridge, England).

\section{Cumulative mortality percent}

The cumulative mortalities of the remained challenged fish groups ( $\mathrm{n}=15$ fish/group) were recorded daily for up to 7 days. They were fed on the same experimental diets as previously described.

\section{Statistical analysis}

The data obtained were statistically analyzed by analysis of variance (ANOVA) in a general linear model procedure using SPSS 20.0 software. If fixed effect were found significant, Duncan's multiple range tests was used for pairwise comparison. Values are expressed as means \pm standard error. Differences with $\mathrm{p}<0.05$ are considered significant.

\section{Results}

\section{Assessment of growth performance and feed utilization}

We examined the effect of diets supplemented with S. platensis (SP), Garlic (GP) or a mixture of both (SP + GP) on growth performance of O. niloticus (Table 3). Initial weights of treatment and control groups at the start of the experiment were similar $(\mathrm{P}>0.05)$. At the end of the feeding trial, fish supplemented with SP, GP or SP+GP mixture grew significantly more than the control group. Final weight was significantly higher $(\mathrm{P}<0.05)$ in SP group (by 8.75\%), GP group (by $15.75 \%$ ) and SP + GP group (by 20.1\%) compared to the control group. Weight gain was also significantly higher in SP + GP group (by $41.65 \%$ ), GP (by $33.48 \%$ ) and SP (by $20.56 \%$ ) versus the control. SGR was significantly higher in all groups compared to control. The results of food utilization in terms of FCR and PER showed significant improvements in both of all treated groups with respect to control group. 
Citation: Abu-Elala NM, Galal MK, Abd-Elsalam RM, Mohey-Elsaeed O, Ragaa NM (2016) Effects of Dietary Supplementation of Spirulina platensis and Garlic on the Growth Performance and Expression Levels of Immune-related Genes in Nile tilapia (Oreochromis niloticus). J Aquac Res Development 7: 433. doi:10.4172/2155-9546.1000433
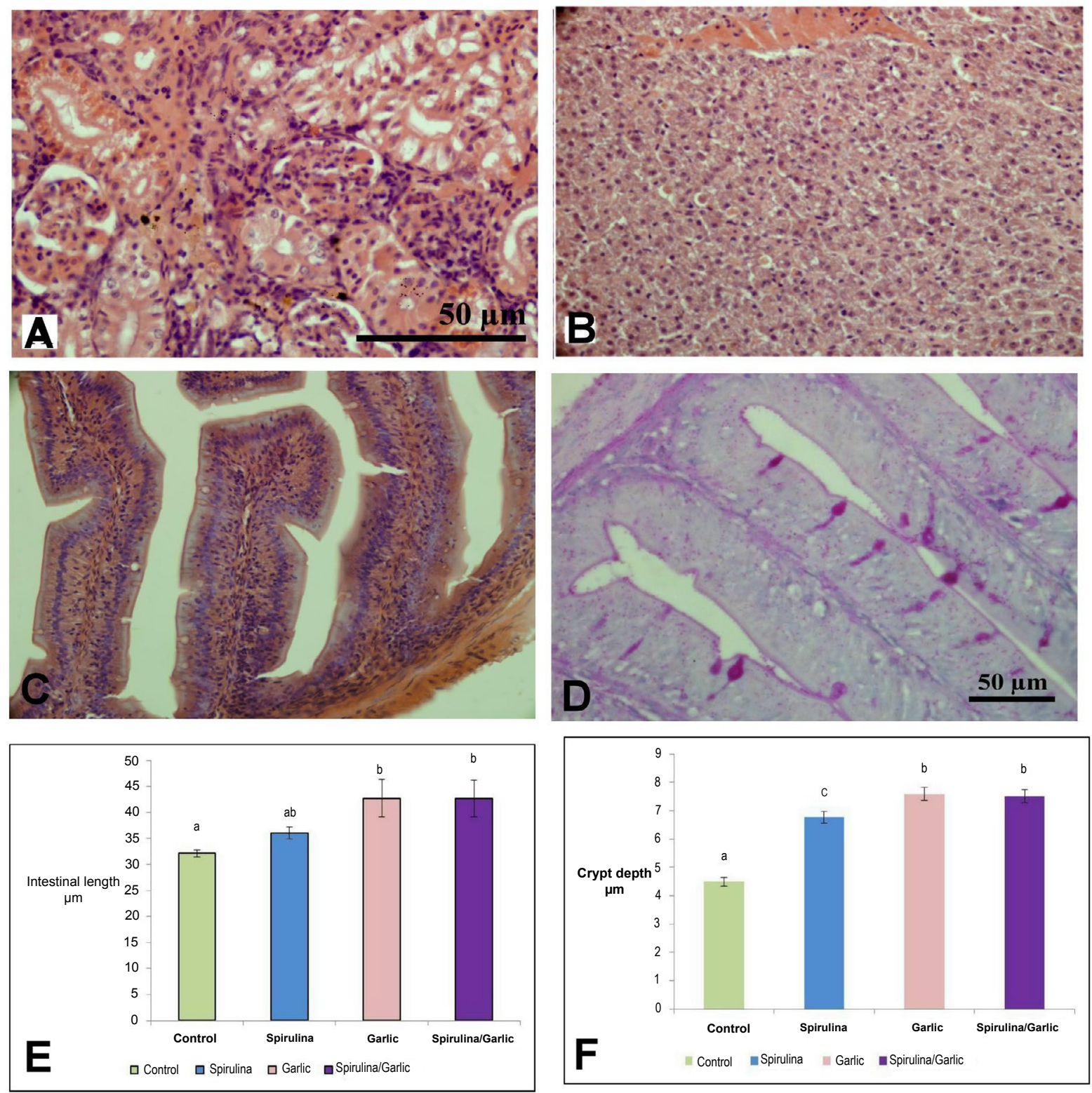

Figure 1: Normal histological findings were seen in Kidney (A) and Liver (B). The intestine show intact mucosal lining of intestinal villi (C). A thin layer of mucus secretion presents on the apical surface of the epithelial cells which is positive to PAS staining along with goblet cells (D). There is significant increase in the intestinal villi length of all supplemental groups compared with control group (E). Fish groups fed on phytobiotic mixture (SP + GP) and (GP) showing significant increase in the crypt depth compared to $(\mathrm{SP})$ group which has higher crypt depth than control $(F)$. Vertical bars represented the mean $\pm S E$ ( $n=5 / \mathrm{group} /$ replicate); different letters indicate significant difference among groups $(P<0.05)$ according one way ANOVA followed by Duncan's multiple range test.

\section{Histological findings}

Normal histological structures were seen in kidney, liver and intestine. The kidney showed normal renal structure (Figure 1A). The liver in different fish groups exhibited normal histological structure demonstrated as evenly distributed polygonal hepatocytes with central spherical nucleus, as well as intact blood vessels and sinusoids of different sizes (Figure 1B). The intestinal villi with intact mucosal lining were observed (Figure 1C). A thin layer of mucus secretion could be seen on the apical surface of the epithelial cells which was positive to PAS staining along with goblet cells (Figure 1D). A significant increase in the length of intestinal villi of (SP+GP), GP groups and SP group respectively was observed as compared to control (Figure 1E). The lengths of crypt depth were significantly increased in (SP + GP) and GP groups compared to SP group and in all supplementation compared to control (Figure 1F).

\section{Immunological assays}

All treated groups showed significant increase in respiratory burst activity and serum lysozyme activity $(P<0.05)$ pre and post bacterial infection (Figures $2 \mathrm{~A}$ and $2 \mathrm{~B}$ ). The highest respiratory burst activity was recorded in fish group fed on SP + GP, and in all supplementations compared to control (Figure 2A). There was significant increase in serum lysozyme activities of all treated groups versus control group before infection while the higher increase was recorded in phytobiotic mixture treated group post infection (Figure 2B). 
Citation: Abu-Elala NM, Galal MK, Abd-Elsalam RM, Mohey-Elsaeed O, Ragaa NM (2016) Effects of Dietary Supplementation of Spirulina platensis and Garlic on the Growth Performance and Expression Levels of Immune-related Genes in Nile tilapia (Oreochromis niloticus). J Aquac Res Development 7: 433. doi:10.4172/2155-9546.1000433

Page 5 of 10

\section{Real-time PCR}

The expressions of TNF- $\alpha$ and hepcidin genes in the spleen and liver of O. niloticus shown in Figures 2C and 2D. Highest expression of TNF- $\alpha$ was detected in mixed and GP groups $(\mathrm{P}<0.05)$ compared with SP and control groups before and after infection. There was no significant difference between groups in the expression levels of liver hepcidin before infection while, post infection there was significant
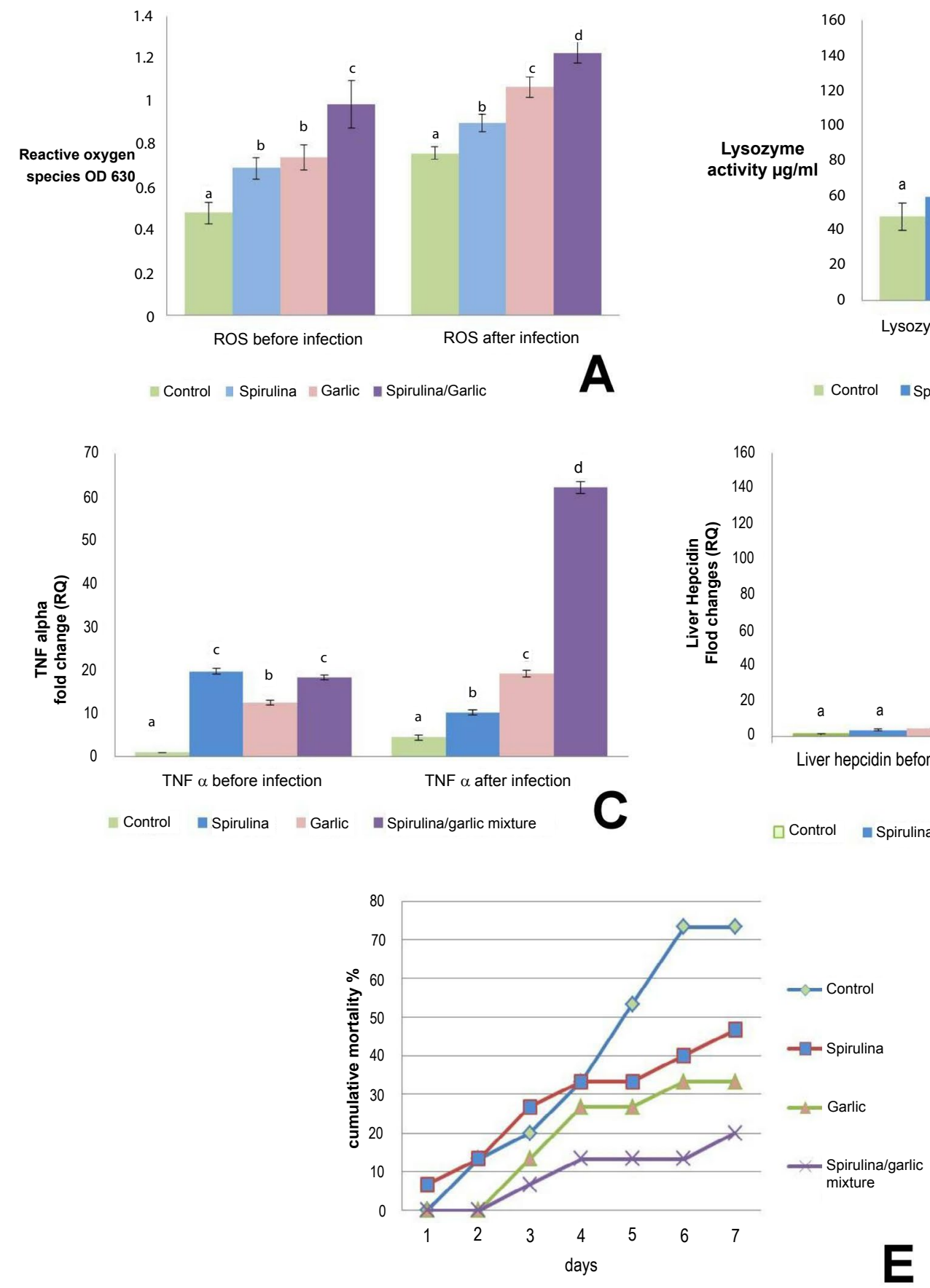

Figure 2: Effects of S. platensis, Garlic and mixture (SP + GP) on the innate immunity of $O$. niloticus before and after bacterial infection (A) Respiratory burst activity and (B) lysozyme activity, (C) Quantitative real-time PCR analysis of mRNA level of TNF-a gene and (D) hepcidin gene. Vertical bars represented the mean \pm SE $(n=5 / g r o u p / r e p l i c a t e)$; different letters indicate significant difference among groups $(P<0.05)$ according one way ANOVA followed by Duncan's multiple range test. $(E)$ Cumulative mortality percent of fish groups challenged IP with $A$. hydrophila.

up-regulation in fish group fed on SP + GP mixture $(\mathrm{p}<0.05)$ and SP compared to GP (Figure 2D) and control positive group.

\section{The histopathological results}

In control group challenged with $A$. hydrophila, the liver showed multiple patchy areas of hepatocellular necrosis with inflammatory cells and bacterial aggregations (Figure 3A1), marked vacuolar degeneration of hepatocytes and necrosis of the hepatopancrease. The
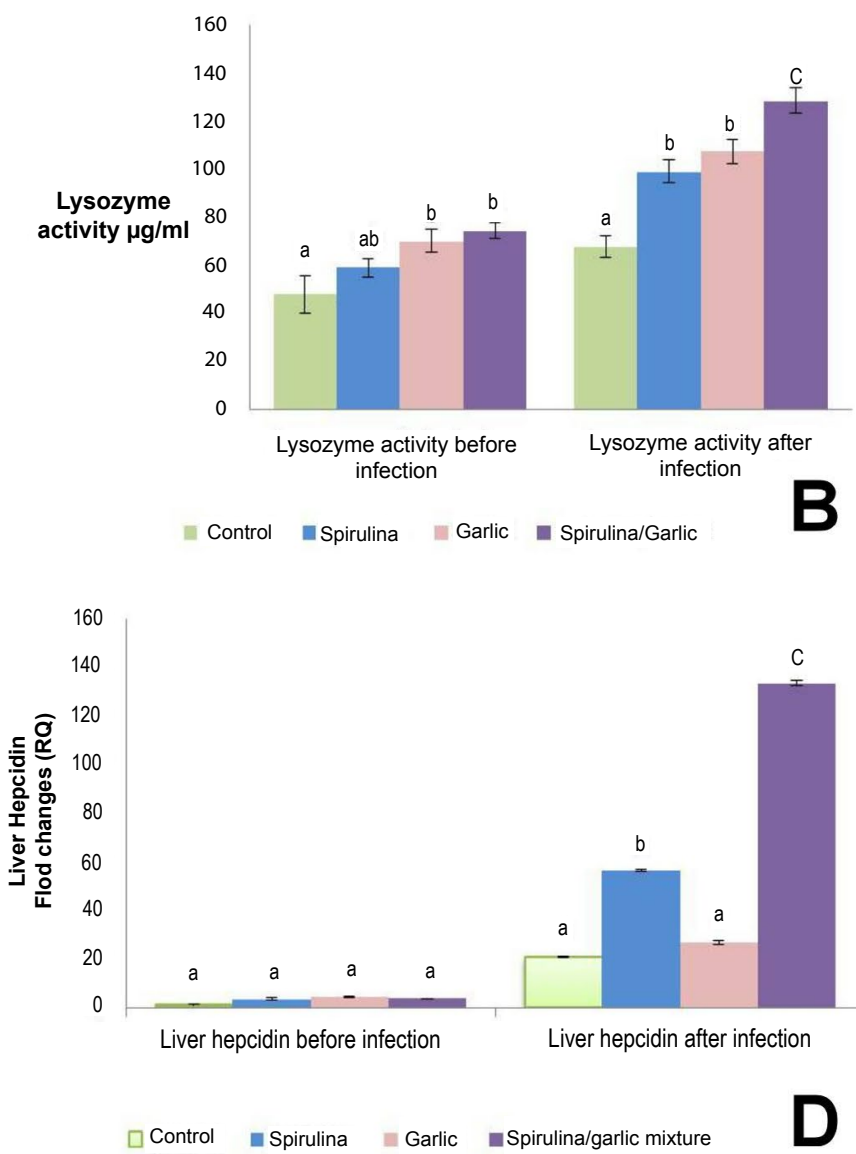

$\square$ Control $\backsim$ Spirulina $\backsim$ Garlic $\backsim$ Spirulina/garlic mixture 
Citation: Abu-Elala NM, Galal MK, Abd-Elsalam RM, Mohey-Elsaeed O, Ragaa NM (2016) Effects of Dietary Supplementation of Spirulina platensis and Garlic on the Growth Performance and Expression Levels of Immune-related Genes in Nile tilapia (Oreochromis niloticus). J Aquac Res Development 7: 433. doi:10.4172/2155-9546.1000433
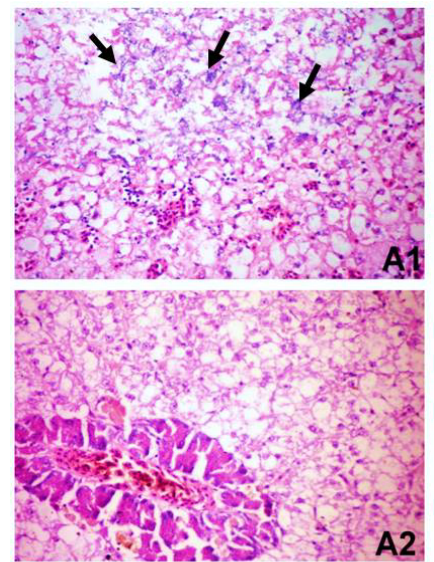

A2.
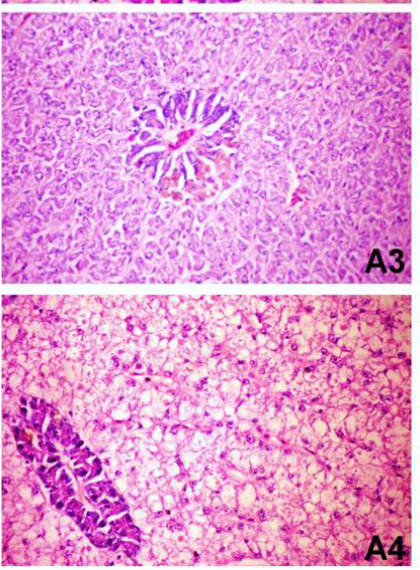
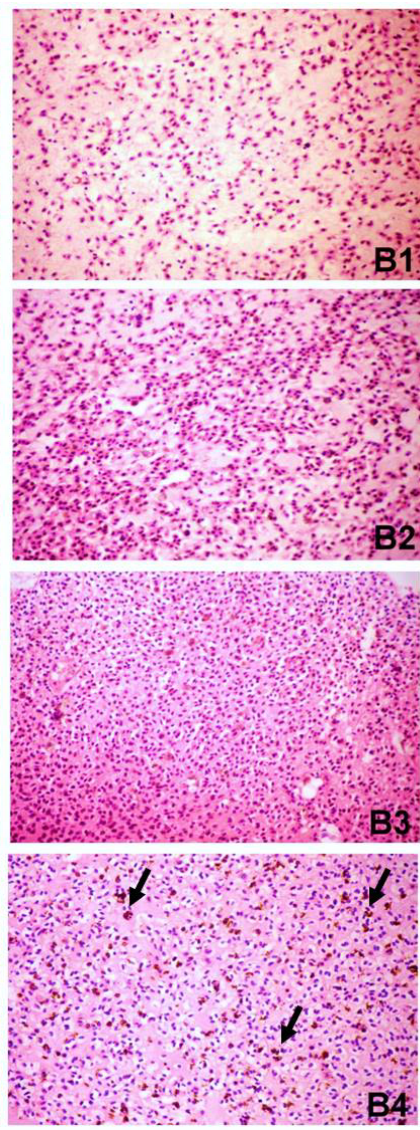
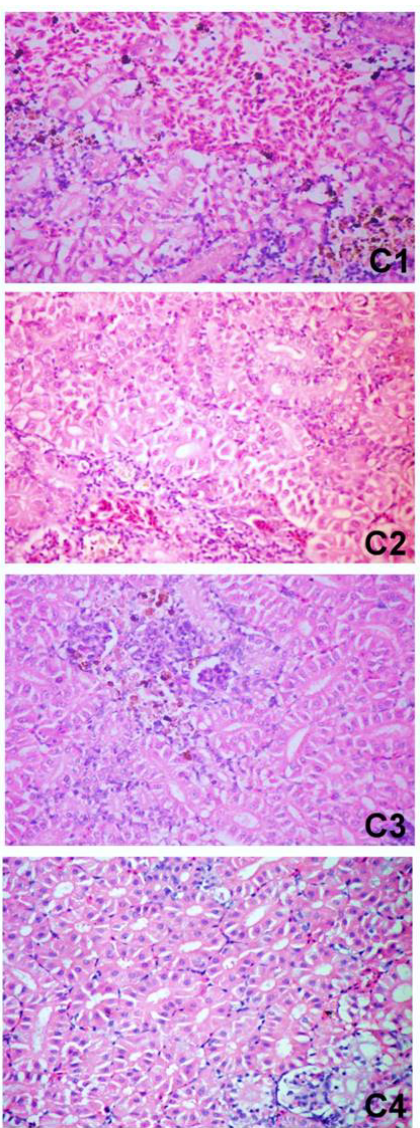

Figure 3: A-Photomicrograph of liver of the different experimental groups after bacterial challenge ( $\mathrm{n}=5 / \mathrm{group} / \mathrm{replicate)}$; (A1) Control group showing marked hepatocellular necrosis with inflammatory cells and bacterial aggregations (arrow) (H\&E X400); (A2) (SP)group showing moderate vacuolation of hepatocytes with individual cell necrosis (H\&E X400); (A3) (GP) group showingmild vacuolation of hepatocytes (H\&E X400). (A4) (SP + GP) group showingmoderate vacuolation of hepatocytes with single cell necrosis (H\&E X400). B-Photomicrograph of anterior kidney of the different experimental groupsafter bacterial challenge; (B1) Controlgroup showing marked depletion of hembiotic elements (H\&E X400); (B2) (SP) group showing mild depletion of hemobiotic elements (H\&E X400); (B3) (GP)group showing mild depletion of hemobiotic elements with activation of MMCS (H\&E X400); (B4) (SP + GP)group showing mild depletion of hemobiotic elements with numerous MMCs (arrow) (H\&E X400). C- Photomicrograph of posterior kidney of the different experimental groupsafter bacterial challenge; (C1) Controlgroup showing interstitial hemorrhage, marked vacuolar degeneration of the renal tubular epithelium and renal tubular necrosis with inflammatory cell infiltration (H\&E X400); (C2) (SP)group showing moderate vacuolar degeneration of renal tubular epithelium with individual cell necrosis with mild inflammatory cell infiltration (H\&E X400); (C3) (GP)group showing mild vacuolar degeneration of renal tubular epithelium (H\&E X400); (C4) (SP + GP)group showing normal histological finding of kidney (H\&E X400).

anterior kidney revealed marked depletion of hemopoietic elements and slight activation of melanomacrophage centers (MMCs) (Figure 3B1). The posterior kidney revealed interstitial hemorrhage, marked vacuolar degeneration of the renal tubular epithelium with renal tubular necrosis (Figure 3C1) and depletion of the hemopoietic elements. Spleen showed marked depletion of hemopoietic elements, lymphoidal necrosis and slight activation of MMCs. In (SP) group post infection, the liver showed mild hepatocellular necrosis and marked vacuolar degeneration of hepatocytes (Figure 3A2). The anterior kidney revealed mild depletion of hemopoietic elements and moderate activation of MMCs (Figure 3B2). The posterior kidney revealed moderate vacuolar degeneration of renal tubular epithelium with individual cell necrosis (Figure 3C2). The spleen showed slight depletion of hemopoietic elements, slight lymphoidal necrosis and moderate activation of MMCs. In (GP) group, the liver showed mild hepatocellular necrosis and mild vacuolar degeneration of hepatocytes (Figure 3A3). The anterior kidney revealed slight necrosis of hemopoietic elements and moderate activation of MMCs (Figure 3B3). The posterior kidney revealed mild vacuolar degeneration of renal tubular epithelium with individual cell necrosis (Figure 3C3). The spleen showed slight depletion of hemopoietic elements, slight lymphoidal necrosis and moderate activation of MMCs. In fish group fed on phytobiotic mixture, the liver showed mild hepatocellular necrosis and mild vacuolar degeneration of hepatocytes (Figure 3A4). The anterior kidney revealed slight depletion of hemopoietic elements and marked activation of MMCs (Figure 3B4). The posterior kidney revealed mild vacuolar degeneration of renal tubular epithelium with individual cell necrosis (Figure 3C4). The spleen showed slight depletion of hemopoietic elements, slight lymphoidal necrosis and marked activation of MMCs.

\section{Immunohistochemical analysis of TNF- $\alpha$ after Aeromonas hydrophila challenge}

Figure 4 showed the localization of TNFa immunopostive cells in different tissues of the experimental group. Figure 5 demonstrated the results of Immunohistochemical evaluation of TNF- $\alpha$ expression in the anterior kidney of different groups. The dark brown stained cells are considered positive (Figures 5A-5E). Fish group fed on phytobiotic mixture (SP + GP) had the highest percentage of TNF- $\alpha$ immunestaining cells, followed by (GP) group which was significantly higher than (SP) group versus to control group (Figure 4F). 
Citation: Abu-Elala NM, Galal MK, Abd-Elsalam RM, Mohey-Elsaeed O, Ragaa NM (2016) Effects of Dietary Supplementation of Spirulina platensis and Garlic on the Growth Performance and Expression Levels of Immune-related Genes in Nile tilapia (Oreochromis niloticus). J Aquac Res Development 7: 433. doi:10.4172/2155-9546.1000433
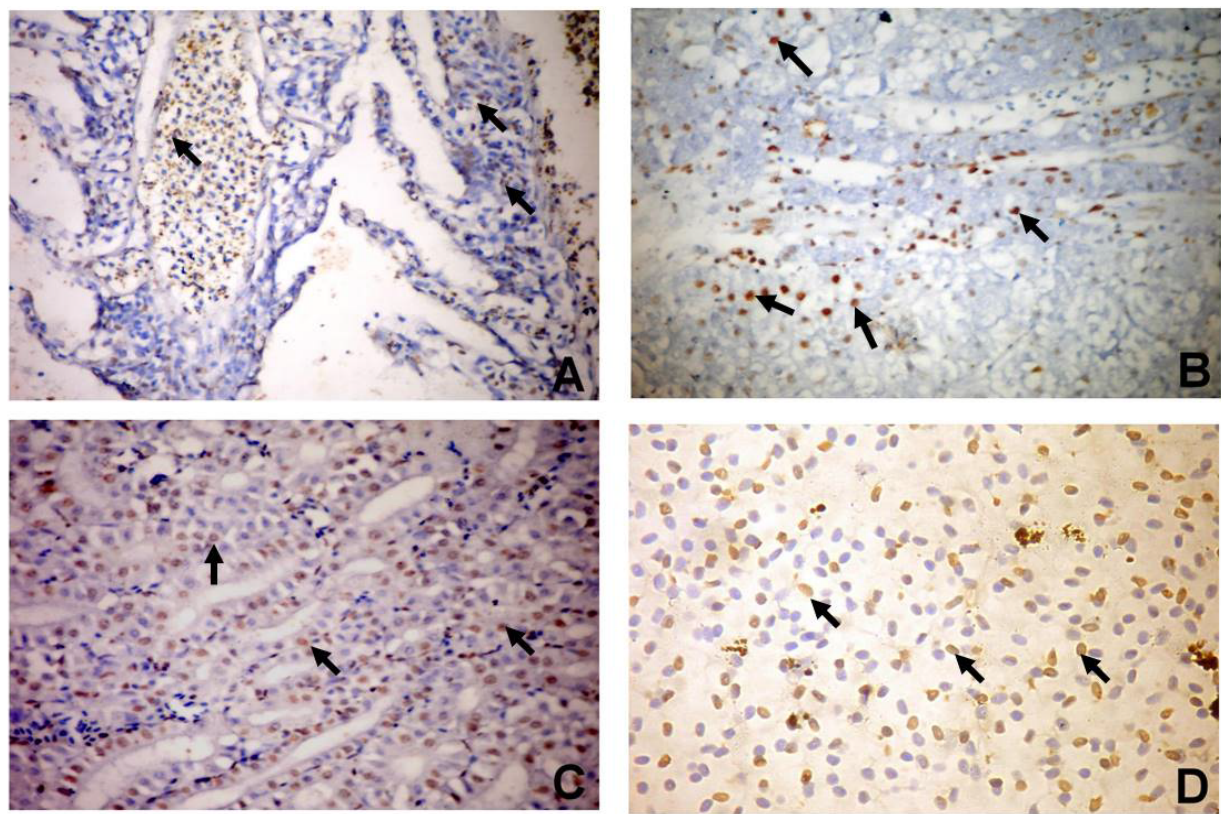

Figure 4: Photomicrograph of TNFa immunopostive cells (arrows) in different tissues of (SP + GP) group. A. Gills (X400); B. Liver (X400); C. Posterior kidney (X400); D. Anterior kidney $(\mathrm{X} 1000)(\mathrm{n}=5 / \mathrm{group} / \mathrm{replicate})$.
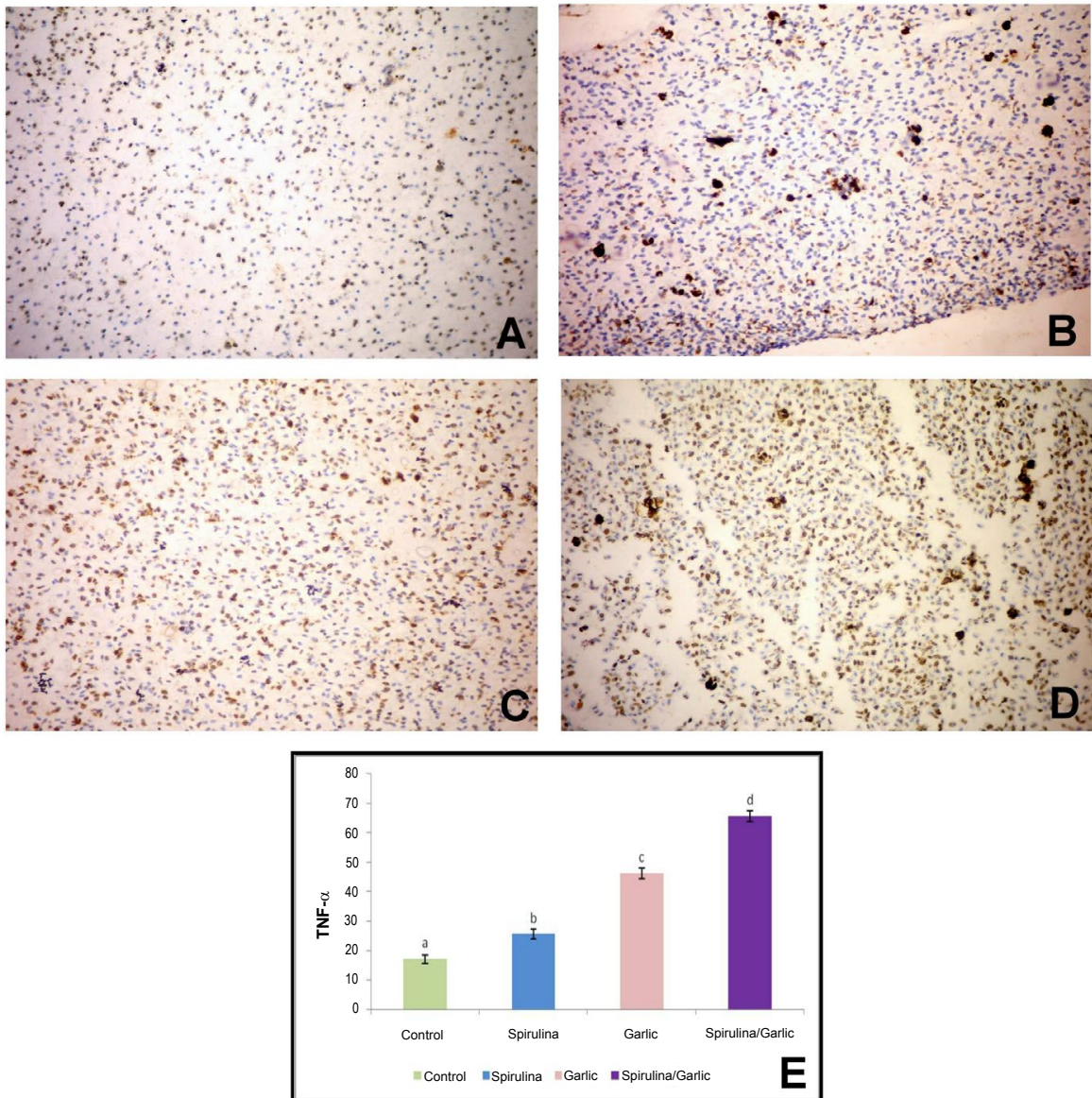

Figure 5: Representative TNFa immunohistochemistry in the anterior kidney tissue of different experimental groups ( $\mathrm{n}=5 / \mathrm{group} / \mathrm{replicate}$ ). A. Control group showing very weak TNFa immunostaining reaction (X400); B. (SP) group showing mild immunostaining reaction in cells (arrows) (X400); C. (GP) group showing rise in the number of TNFa immunostained cells (arrow) comparing with (SP) group (X400); D. (SP + GP) group showing strong immunopositive reaction in numerous cells (arrows) (X400) E. The bar chart represents TNFa positive cells expressed as \% of the total cell count. Values with different superscripts are significantly different $(\mathrm{P}<0.05)$. 


\section{Challenge test}

The mean cumulative mortality of the experimental fish groups 7 days post challenge with $A$. hydrophila showed that, the highest mortality rate $(73.3 \%)$ was recorded in control group compared with the treated groups, which showed (46.67\%) mortality percent in (SP) group, (40\%) in (GP) group and the least mortality (20\%) was recorded in mixed feed additives treated group (Figure 2E).

\section{Discussion}

According to our study, the parallel use of Garlic and Spirulina alone or in combination showed significant improvement in the growth performance of tilapia. Dietary inclusion of Spirulina in aquafeed increases the appetite, feed intake and nutrient digestibility of cultured fish. These were notably detected in final weight, weight gain and SGR. This is consistent with some previous reports $[10,13,43,44]$. The lack of cellulose from the cellular structure of Spirulina and presence of mucopolymer murein renders it easily digested by digestive enzymes of fish [12]. Moreover it stimulates the flourishing of beneficial intestinal flora in fish and improves the breakdown of indigestible feed components $[10,12]$. PER and FCR were significantly improved in Spirulina supplemented group versus control. The highly digestible protein, vitamin B12 and minerals help in fish growth. The well balanced amino acids of Spirulina compared with other plant protein makes it a potential replacer of fish meal in aquafeed formulation [45]. It has been used to replace up to $40 \%$ of fish meal protein in tilapia O. mossambicus and up to $7 \%$ in parrot fish Oplegnathus fasciatus [46,47]. Nandeesha et al. [48] and Guroy et al. [49] reported that body weight gain of fish increased linearly with increasing the level of algae in fish diet at levels less than $25 \%$. On the contrary Ungsethaphand et al. [50] recorded in significant improvement in growth performance of hybrid tilapia after Spirulina supplementation. The difference of Spirulina concentration, source, raw or dried, fish species and rearing conditions may be reasons of these variable results. Literature revealed significant increment in the growth performance of cultured $O$. niloticus after feeding on diet supplemented with garlic $[27,44,51]$ but they used more higher levels of garlic powder than that was used in our study. Irkin et al. [29] and Lee et al. [30] suggested that garlic powder supplementation in diets for Sea bass (Dicentrarachus labrax) juveniles and Sterlet sturgeon (Acipenser ruthenus) fingerlings respectively shouldn't exceed $2 \%$ and justified their findings as the high doses of garlic appeared to be harmful to fish health. This may be because too much alkyl sulfide reaches the intestine, interfering with normal metabolism and suppressing intestinal mitosis, resulting in slow growth and even death. Aly and Mohamed [24] reported that high dose of garlic or long feeding period was needed to enhance the growth rate of Nile tilapia. Certainly, it has been disputed that the long term use of immunostimulants leads to immunesuppression and loss of effect of the compounds [52] and the high dose could affect the fish health. Dietary supplementation of Garlic $(5 \mathrm{~g} / \mathrm{kg})$ showed significant increase in final weight, weight gain and SGR (Table 3 ). The growth potentiating effect of garlic is depending on the most effective ingredient allicin which is responsible for intense garlic flavor and strong stimulatory effect on olfaction in most aquatic animals [21]. It has a strong food calling effect, improves gastrointestinal motility, and modulates the secretion of various digestive enzymes to improve digestion and nutrient absorption. It also promotes the performance of the intestinal flora, inhibits deleterious bacteria while intensifying beneficial bacteria such as lactobacillus and bifidus, thereby enhancing the utilization of energy and improving growth [53]. It's worthy to note that, allicin is unstable bio-active compound, so the efficiency of garlic may vary considerably by species and preparation. This could justify the growth potentiating effect of low garlic concentration that has been used in this study compared with the previous literature. PER and FCR were significantly improved in garlic supplemented group similar to the results obtained by Shalaby et al. [51] and Metwally [27]. Dietary garlic increased the protein content of whole fish and decreased the lipid and ash contents [27]. Several effects of garlic could be involved in the increment of protein efficiency and fish growth. Allicin could activate intestinal proteases which convert feed protein into fish protein, increasing the content of palatable amino acids [21]. Most of fish diet is lacking amino acids that generate an aroma and palatable taste such as, histidine, leucine, aspartic acid and valine. The fragrant ingredients of fish are generally sulfer-containing base groups. Biochemical analysis has indicated that garlic contains various alkyl sulfide compounds which relate to flesh aroma and increases the fish quality. Allicin also reacts with vitamin B1 forming allithiamine which can inhibit the decomposing effect of thiaminase, ensuring the supplication of vitamin $\mathrm{B} 1$ and improved growth in fish [21]. The highest growth performance parameters have been detected in fish groups fed on the phytobiotic mixture, that mean garlic can work synergistically with Spirulina. Intestinal length and crypt depth are indicators of the digestive capacity of small intestine. Assessment of the intestinal morphometry of the treated groups showed significant increases in the mean values of villi length. This represents an increase in the absorptive surface area of the intestine which in turn increases the body weight gain and decreases the FCR. Also the values of mean cryptal depth in supplemented groups were significantly higher than control. Since crypt cells are responsible for secretion of electrolytes which enhance water secretion into the intestinal lumen for the purpose of digestion. Stem cells at the base of crypts are known to be the factory of all cells lining the crypt and villus. Thus, a higher cryptal depth is indication of a higher mucosal proliferation [54]. The higher villi length may be related to the higher protein contents in Spirulina (55-65\%). it includes all of the essential amino acids especially tryptophan and arginine which play a significant role to keep the maintenance of the intestinal epithelium [55]. Also the presence of amino acid arginine and glutamic acid in garlic beside the higher potentiality of garlic allicin to improve the protein assimilation could influence the gut health. The healthy gut of treated fish groups may explain the improved growth performance.

The present study indicated that fish groups fed on phytobiotic mixture exhibited the least mortality present post challenge with $A$. hydrophila (20\%) followed by GP (40\%) and SP (46.67\%). Several antimicrobial bioactive compounds are found in both herbs. Each compound has its own mode of action against microorganisms. It was hypothesized that polyphenol, fatty acids, glycolipid and alkaloids in Cyanobacteria $[14,16]$ can kill microorganisms by penetrating the cell wall without visible changes and reach the cell membrane leading to its disintegration or interfere with the microbial cell metabolic pathways. While the antibiotic effect of garlic could be attributed to the inhibition of certain thiol-containing enzyme in microorganisms. The thiosulfinate compounds in garlic oxidize the intracellular bacterial thiol content [21]. Allicin can also completely inhibit RNA synthesis and partially inhibit DNA and protein synthesis [56]. Lectin is regarded as the most abundant protein in garlic. It binds to bacterial cells via mannose binding lectin, preventing the attachment of the $A$. hydrophila on the fish gut. Also this binding triggers the complement cascade and subsequently, the process of phagocytosis [52]. Activation of phagocytic cell upon administration of immunostimulants might induce other antimicrobial mechanisms. Production of reactive oxygen species (ROS) by the immune cells might explain the significant increase in respiratory burst activity of the neutrophils. These reactive oxygen radicals are known to be toxic to pathogenic bacteria [52] 
Citation: Abu-Elala NM, Galal MK, Abd-Elsalam RM, Mohey-Elsaeed O, Ragaa NM (2016) Effects of Dietary Supplementation of Spirulina platensis and Garlic on the Growth Performance and Expression Levels of Immune-related Genes in Nile tilapia (Oreochromis niloticus). J Aquac Res Development 7: 433. doi:10.4172/2155-9546.1000433

Furthermore, the lysozyme secreted by leukocytes attacks the bacterial cell wall, prevents their adhesion and colonization. Lipoproteins and high molecular weight polysaccharide (Immolina) ${ }^{\circ}$ of Spirulina cell wall play important roles in activation of the immune system; they act as ligands to immune cell receptors. They have the ability to increase the mRNA levels of various chemokines and cytokines like IL- $1 \beta$ and TNF- $\alpha[6,19]$.

TNFs are potent pro-inflammatory cytokines implicated in inflammation, apoptosis, and cell proliferation and in stimulation of various aspects of immune system involved in prophylaxis against pathogens [19,57]. Garlic treated group showed significant upregulation in TNFa pre/post bacterial infection [58]. Sung et al. [57] found that although garlic has increased LPS-induced TNF- $\alpha$. This elevation is for short term followed by subsequent decrease in the level of this cytokine. This evidence justifies how the garlic has both immunostimulatory and anti-inflammatory effects. On the other hand Spirulina treated group showed significant increase in TNF- $\alpha$ expression post infection [19] but lesser than that found in garlic. The fish group fed on both feed additives exposed the highest expression of TNFa.

Antimicrobial peptides (AMPs) are small, cationic, hydrophobic immune-mediators of fish against bacteria. Hepcidin is one of these peptides, it's a highly disulphide bonded (rich in cysteine) $\beta$-sheets peptide. It plays an important role in non-specific immunity and iron regulation $[59,60]$. Liver- produced hepcidin to control plasma iron levels by regulating the absorption of dietary iron from intestine, the release of recycled hemoglobin iron by macrophages and the movement of stored iron from hepatocytes [61]. During infection, fish groups fed on Spirulina alone or phytobiotic mixture, showed significant up-regulation of hepcidin gene. It binds to ferroprotein and triggers its degradation, resulting in hypoferremia. The better absorbed iron in Spirulina could increase the iron loading in tissue [62] and this may be the reason for up-regulation level of hepcidin in SP and (SP + GP) groups. Arezes et al. [63] confirmed that one of the host defense mechanism is hepcidin-mediated hypoferremia that evolved to restrict iron availability for pathogen growth. The quantification results of both genes demonstrated that, TNF $\alpha$ was higher in GP group than in SP group on the contrast, the expression of hepcidin gene was higher in SP group than in GP group. These could be attributed to the higher expression of TNF- $\alpha$ is inversely affects the expression of hepcidin gene [64]. It has been found that TNF- $\alpha$ inhibits the release of iron from macrophages inducing hypoferremia and consequently hepcidin levels may be affected. Surprisingly, fish groups fed on phytobiotic mixture revealed significant up-regulation in the levels of both immune-related genes and this need more investigation.

\section{Conclusion}

In conclusion, this study reinforces the view that phytobiotics are beneficial for modulation the growth performance and non-specific immunity of fish. Based on the current study the phytobiotic mixture composed of garlic and Spirulina is recommended as a potential nutraceuticals and immunostimulant feed additives in cultured tilapia.

\section{Acknowledgement}

We would like to express our sincere gratitude for Dr. Waleed Fawzy Marei, Lecturer of Theriogenology, Faculty of Veterinary Medicine; Cairo University for his precious linguistic reviewing of manuscript.

\section{References}

1. Selim KM, Reda RM (2015) Improvement of immunity and disease resistance in the Nile tilapia, Oreochromis niloticus, by dietary supplementation with Bacillus amyloliquefaciens. Fish Shellfish Immunol 44: 496-503.
2. Syahidah A, Saad CR, Daud HM, Abdelhadi YM (2015) Status and potential of herbal applications in aquaculture: A review. Iranian Journal of Fisheries Sciences 14: 27-44.

3. Akhter N, Wu B, Memon AM, Mohsin M (2015) Probiotics and prebiotics associated with aquaculture-A Review. Fish Shellfish Immunol 45: 733-741.

4. Peterson BC, Peatman E, Ourth DD, Waldbieser GC (2015) Effects of a phytogenic feed additive on growth performance, susceptibility of channel catfish to Edwardsiella ictaluri and levels of mannose binding lectin. Fish Shellfish Immunol 44: 21-25.

5. Adel M, Abedian AA, Zorriehzahra J, Nematolahi A, Esteban MÁ (2015) Effects of dietary peppermint (Mentha piperita) on growth performance, chemical body composition and hematological and immune parameters of fry Caspian white fish (Rutilus frisii kutum). Fish Shellfish Immunol 45: 841-847.

6. Ravi, Maddaly, Sai LD, Syed A, Solomon FD (2010) The beneficial effects of Spirulina focusing on its immunomodulatory and antioxidant properties. Nutr Diet Suppl 2: 73-83.

7. Capelli B, Cysewski GR (2010) Potential health benefits of spirulina microalgae Nutrafoods 9: 19-26.

8. Hosseini SM, Khosravi-Darani K, Mozafari MR (2013) Nutritional and medical applications of spirulina microalgae. Mini Rev Med Chem 13: 1231-1237.

9. Habib M, Ahsan B, Mashuda P, Tim C, Mohammad RH, et al. (2008) A review on culture, production and use of spirulina as food for humans and feeds for domestic animals and fish. Food and agriculture organization of the united nations.

10. Ibrahem MD, Mohamed MF, Ibrahim M (2013) The role of Spirulina platensis (Arthrospira platensis) in growth and immunity of Nile Tilapia (Oreochromis niloticus) and its resistance to bacterial infection. J Agric Sci 5: 109-117.

11. Jafari SMA, Rabbani M, Emtyazjoo M, Piryaei F (2014) Effect of dietary Spirulina platensis on fatty acid composition of rainbow trout (Oncorhynchus mykiss) fillet. Aquac Int 22: 1307-1315.

12. Teimouri M, Amirkolaie AK, Yeganeh S (2013) The effects of Spirulina platensis meal as a feed supplement on growth performance and pigmentation of rainbow trout (Oncorhynchus mykiss). Aquaculture 396: 14-19.

13. Abdulrahman NM, Ameen HJ (2014) Replacement of fishmeal with microalgae spirulina on common carp weight gain, meat and sensitive composition and survival. Pakistan Journal of Nutrition 13: 93.

14. Mala R, Sarojini M, Saravanababu S, Umadevi G (2009) Screening for antimicrobial activity of crude extracts of Spirulina platensis. J Cell Tissue Res 9: 1951-1955.

15. Chu WL, Lim YW, Radhakrishnan AK, Lim PE (2010) Protective effect of aqueous extract from Spirulina platensis against cell death induced by free radicals. BMC Complement Altern Med 10: 53.

16. Sudha SS, Karthic R, Rengaramanujam J (2011) Antimicrobial activity of Spirulina platensis and Aphanothece sp. on selected clinical bacterial isolates and its antioxidant activity. South Asian J Biol Sci 1: 87-98.

17. Hetta M, Mahmoud R, El-Senousy W, Ibrahim M, El-Taweel G, et al. (2014) Antiviral and antimicrobial activities of Spirulina platensis. World $\mathrm{J}$ Pharm Pharm Sci 3: 31-39.

18. Tayag CM, Lin YC, Li CC, Liou CH, Chen JC (2010) Administration of the hotwater extract of Spirulina platensis enhanced the immune response of white shrimp Litopenaeus vannamei and its resistance against Vibrio alginolyticus. Fish Shellfish Immunol 28: 764-773.

19. Watanuki H, Ota K, Tassakka ACMAR, Kato T, Sakai M (2006) Immunostimulant effects of dietary Spirulina platensis on carp, Cyprinus carpio. Aquaculture 157-163.

20. Lin YC, Tayag CM, Huang CL, Tsui WC, Chen JC (2010) White shrimp Litopenaeus vannamei that had received the hot-water extract of Spirulina platensis showed earlier recovery in immunity and up-regulation of gene expressions after pH stress. Fish Shellfish Immunol 29: 1092-1098.

21. Lee J, Gao Y (2012) Review of the application of garlic, Allium sativum, in Aquaculture. J World Aquac Soc 43: 447-458.

22. Nya EJ, Dawood Z, Austin B (2010) The garlic component, allicin, prevents disease caused by Aeromonas hydrophila in rainbow trout, Oncorhynchus mykiss (Walbaum). J Fish Dis 33: 293-300.

23. Agbebi OT, Ogunmuyiwa TG, Herbert SM (2013) Effect of dietary garlic source 
Citation: Abu-Elala NM, Galal MK, Abd-Elsalam RM, Mohey-Elsaeed O, Ragaa NM (2016) Effects of Dietary Supplementation of Spirulina platensis and Garlic on the Growth Performance and Expression Levels of Immune-related Genes in Nile tilapia (Oreochromis niloticus). J Aquac Res Development 7: 433. doi:10.4172/2155-9546.1000433

Page 10 of 10

on feed utilization, growth and histopathology of the African catfish (Clarias gariepinus). J Agric Sci 5: 26-34.

24. Aly SM, Atti NM, Mohamed MF (2008) Effect of garlic on the survival, growth, resistance and quality of Oreochromis niloticus. International Symposium on Tilapia in Aquaculture 2008: 277-296.

25. Jegede T (2012) Effect of garlic (Allium sativum) on growth, nutrient utilization, resistance and survival of Tilapia zillii (Gervais 1852) Fingerlings. J Agric Sci 4: $269-274$.

26. Megbowon I, Adejonwo OA, Adeyemi YB, Kolade OY, Adetoye EB, et al. (2013) Effect of garlic on growth performance, nutrient utilization and survival of an ecotype cichlid,'Wesafu'. IOSR JAVS 6: 10-13.

27. Metwally MA (2009) Effects of garlic (Allium sativum) on some antioxidant activities in tilapia Nilotica (Oreochromis niloticus). World J fish mar sci 1: 56-64.

28. Al-Salahy MB, Mahmoud AA (2003) Metabolic and histological studies on the effect of garlic administration on the carnivorous fish Chrysichthys auratus. Egypt J Bot 5: 94-107.

29. Irkin LC, Yigit M, Yilmaz S, Maita M (2014) Toxicological Evaluation of Dietary Garlic (Allium sativum) Powder in European Sea Bass Dicentrarchus labrax Juveniles. Food and Nutrition Sciences 989-996.

30. Lee DH, Ra CS, Song YH, Sung K I, Kim JD (2012) Effects of dietary garlic extract on growth, feed utilization and whole body composition of juvenile starle sturgeon (Acipenser ruthenus). Asian-Australasian J Anim Sci 25: 577-583.

31. Ajeel SG, Al-faragi JK (2013) Effect of ginger (Zingiber officinale) and garlic (Allium sativum) to enhance health of common carp, Cyprinus carpio L. The Iraqi $\mathrm{J}$ of Vet Medicine 37: 59-62.

32. Elias NS, El-Ghany NAA (2008) Monitoring the effect of garlic (Allium sativum) and black seed (Nigella sativa) on Fusarium moniliform infection in fish with emphasis on fecundity. Glob Vet 2: 242-249.

33. Kanani HG, Nobahar Z, Kakoolaki S, Jafarian H, Gholipour KH, et al. (2014) Effect of ginger- and garlic-supplemented diet on growth performance, some hematological parameters and immune responses in juvenile Huso huso. Fish Physiol Biochem 40: 481-490.

34. Jauncey K (2000) Nutritional requirements. In Tilapias: biology and exploitation, Springer Netherlands.

35. AOAC (1995) Official methods of analysis of the association official analytical chemists. (16thedn) AOAC International, Arlington, USA.

36. Bancroft JD, Gamble M (2008) Theory and practice of histopathological techniques. Churchill Livingstone New York, London

37. Abarca A, Bethke J, Narváez E, Flores R, Mercado L (2012) Parameters to evaluate the immunostimulant effect of Zymosan A in head kidney leucocytes $(H K L)$ of salmonids/Parámetros para la evaluación del efecto de Zimosán A como inmunoestimulante sobre leucocitos de riñón cefálico (HKL) de salmónidos. Lat Am J Aquat Res 40: 545-552.

38. Abu-Elala NM, Mohamed SH, Zaki MM, Eissa AE (2015) Assessment of the immune-modulatory and antimicrobial effects of dietary chitosan on Nile tilapia (Oreochrmis niloticus) with special emphasis to its bio-remediating impacts. Fish Shellfish Immunol 46: 678-685.

39. Ibrahem MD, Ibrahim M (2014) The potential effects of Spirulina platensis (Arthrospira platensis) on tissue protection of Nile tilapia (Oreochromis niloticus) through estimation of p53 level. J Adv Res 5: 133-136.

40. Schmittgen TD, Livak KJ (2008) Analyzing real-time PCR data by the comparative CT method. Nat Protoc 3: 1101-1108.

41. Abu-Elala N, Abdelsalam M, Marouf S, Setta A (2015) Comparative analysis of virulence genes, antibiotic resistance and gyrB-based phylogeny of motile Aeromonas species isolates from Nile tilapia and domestic fowl. Lett Appl Microbiol 61: 429-436.

42. Ronza P, Losada AP, Villamarín A, Bermúdez R, Quiroga MI (2015) Immunolocalization of tumor necrosis factor alpha in turbot (Scophthalmus maximus, L.) tissues. Fish \& shellfish immunol 45: 470-476.

43. Abdulrahman NM (2014) Evaluation of Spirulina spp. as food supplement and its effect on growth performance of common carp fingerlings. Int J Fish Aquat Stud 2: 89-92.

44. Abdel-Tawwab M, Ahmad MH (2009) Live Spirulina (Arthrospira platensis) as a growth and immunity promoter for Nile tilapia, Oreochromis niloticus (L.), challenged with pathogenic Aeromonas hydrophila. Aquac Res 40: 1037-1046.

45. Hanel R, Broekman D, de Graaf S, Schnack D (2007) Partial replacement of fishmeal by lyophylized powder of the Microalgae Spirulina platensis in Pacific White Shrimp Diets. Open Mar Biol J 1: 1-5.

46. Olvera-Novoa MA, Dominguez-Cen LJ, Olivera-Castillo L, Martínez-Palacio CA, Gilly MC, et al. (1998) Effect of the use of the microalga Spirulina maxima as fish meal replacement in diets for tilapia, Oreochromis mossambicus (Peters), Fryd Aquac Res 29: 709-715.

47. Kim SS, Rahimnejad S, Kim KW (2013) Partial replacement of fish meal with Spirulina pacifica in diets for parrot fish (Oplegnathus fasciatus). Turkish J Fish Aquat Sci 13: 197-204

48. Nandeesha MC, Gangadhara B, Manissery JK, Venkataraman LV (2001) Growth performance of two Indian major carps, catla (Catla catla) and rohu (Labeo rohita) fed diets containing different levels of Spirulina platensis. Bioresour Technol 80: 117-120.49.

49. Güroy B, Şahin I, Mantoğlu S, Kayali S (2012) Spirulina as a natural carotenoid source on growth, pigmentation and reproductive performance of yellow tail cichlid Pseudotropheus acei. Aquac Int 20: 869-878.

50. Ungsethaphand T, Peerapornpisal Y, Whangchai N (2010) Effect of feeding Spirulina platensis on growth and carcass composition of hybrid red tilapia (Oreochromis mossambicus $\times$ O. niloticus). Journal of Science and Technology Reproduction 4: 331-336.

51. Shalaby AM, Khattab YA, Abdel RAM (2006) Effects of garlic (Allium sativum) and chloramphenicol on growth performance, physiological parameters and survival of Nile Tilapia (Oreochromis niloticus). JVATITD 12: 172-201.

52. Nya EJ, Austin B (2011) Development of immunity in rainbow trout (Oncorhynchus mykiss, Walbaum) to Aeromonas hydrophila after the dietary application of garlic. Fish Shellfish Immunol 30: 845-850

53. Diab AS, Aly SM, John G, Abde-Hadi Y, Mohammed MF (2010) Effect of garlic black seed and Biogen as immunostimulants on the growth and survival of Nile tilapia, Oreochromis niloticus (Teleostei: Cichlidae), and their response to artificial infection with Pseudomonas fluorescens. African J Aquat Sci 33: 63-68.

54. Oladele O, Emikpe BO, Bakare $\mathrm{H}$ (2012) Effects of dietary garlic (Allium sativum Linn.) Supplementation on body weight and gut morphometry of commercial broilers. Int J Morphol 30: 238-240.

55. Murakami AE, Fernandes JIM, Hernandes L, Santos TC (2012) Effects of starter diet supplementation with arginine on broiler production performance and on small intestine morphometry. Pesq Vet Bras 32: 259-266.

56. Shakya SR, Labh SN (2014) Medicinal uses of garlic (Allium sativum) improves fish health and acts as an immunostimulant in aquaculture. European Journal of Biotechnology 2: 44-47.

57. Sung J, Harfouche Y, De LCM, Zamora MP, Liu Y, et al. (2015) Garlic (Allium sativum) stimulates lipopolysaccharide-induced tumor necrosis factor-alpha production from J774A. 1 Murine Macrophages. Phytotherapy Research 29 288-294.

58. Tanekhy M, Fall $\mathrm{J}$ (2015) Expression of innate immunity genes in kuruma shrimp Marsupenaeus japonicus after in vivo stimulation with garlic extract (allicin). Vet Med (Praha) 60: 39-47

59. Cuesta A, Meseguer J, Esteban MA (2008) The antimicrobial peptide hepcidin exerts an important role in the innate immunity against bacteria in the bony fish gilthead seabream. Mol Immunol 45: 2333-2342.

60. Ganz T, Nemeth E (2012) Hepcidin and iron homeostasis. Biochim Biophys Acta 1823: $1434-1443$

61. Nemeth E, Tuttle MS, Powelson J, Vaughn MB, Donovan A, et al. (2004 Hepcidin regulates cellular iron efflux by binding to ferroportin and inducing its internalization. Science 306: 2090-2093.

62. Mishra P, Singh VP, Prasad SM (2014) Spirulina and its nutritional importance: A possible approach for Development of Functional Food. Biochem Pharmacol 3: e171.

63. Arezes J, Jung G, Gabayan V, Valore E, Ruchala P, et al. (2015) Hepcidininduced hypoferremia is a critical host defense mechanism against the siderophilic bacterium Vibrio vulnificus. Cell host \& microbe 17: 47-57.

64. Shanmugam NK, Ellenbogen S, Trebicka E, Wang L, Mukhopadhyay S, et al. (2012) Tumor necrosis factor a inhibits expression of the iron regulating hormone hepcidin in murine models of innate colitis. PloS one 7: e38136. 